\title{
Afiks Derivasi Per-/-An dalam Bahasa Indonesia: Tinjauan dari Perspektif Morfologi Derivasi dan Infleksi
}

\author{
Ermanto dan Emidar
}

\begin{abstract}
This article aims to reveal the affixation process using derivational affix per-/-an on Indonesian derived nouns based on the theory of derivational and inflectional morphology. This research was a qualitative research method by using the theory of structural linguistics and case grammar. The object of the research was a derivational affix per-/-an used on Indonesian derived nouns, and the data were sentences (utterances) whose nouns having the derivational affix per-/-an. The analysis method used was a distributional method. Viewed from the perspective of derivational and inflectional morphology, the affixation of the derivational affix per-/-an on the verbs (both base verbs and derived verbs) and on the noun can produce (1) behavioral nouns, (2) Action nouns, (3) actional instrumental nouns, (4) behavioral instrumental nouns, (5) behavioral locative noun, (6) process nouns, (7) collective nouns, (8) abstract nouns.
\end{abstract}

\section{Kata Kunci:}

\section{PENDAHULUAN}

Dalam buku Tata Bahasa Baku Bahasa Indonesia, Alwi, et al. (1998:128) menyatakan bahwa afiks per-/-an umumnya diturunkan dari verba taktransitif (verba perbuatan) yang berawalan ber- seperti perjanjian <-- berjanji, pergerakan <-- bergerak, perjalanan <-- berjalan, pertemuan <-- bertemu, perpindahan <-berpindah. Namun kenyataan, afiks per-/-an ini juga diturunkan dari verba transitif (verba tindakan) seperti pada verba percobaan <-- mencoba bukan dari *bercoba dalam kalimat Amerika Serikat setuju untuk menghentikan percobaan senjata nuklir.

Afiks per-/-an pada verba percobaan diturunkan dari verba tindakan mencoba. Sebagaimana lazimnya, verba tindakan umumnya menurunkan N menggunakan afiks peN-/-an seperti mencari, memungut, memukul, mengambil, menarik yang menurunkan $\mathrm{N}$ pencarian, pemungutan, pemukulan, pengambilan, penarikan. Berdasarkan contoh ini, seharusnya verba tindakan mencoba menurunkan $\mathrm{N}$ pencobaan dengan afiks peN-/-an, tetapi kenyataanya menurunkan $\mathrm{N}$ percobaan dengan afiks per-/-an. 
Permasalahan afiks per-/-an seperti dijelaskan di atas perlu dikaji dari perspektif morfologi derivasi dan infleksi. Permasalahan morfologis yang pada umumnya dapat diamati dalam penurunan kata adalah selalu terdapat penurunan kata yang mengubah identitas leksikal (proses derivasi) dan penurunan kata yang tidak mengubah identitas leksikal (proses infleksi). Morfologi derivasi adalah proses pengubahan bentuk kata yang juga mengubah identitas, sedangkan morfologi infleksi adalah proses pengubahan bentuk kata yang tidak mengubah identitas.

Untuk memahami proses derivasi dan infleksi tersebut, nomina turunan dioposisikan dengan $\mathrm{D}$ atau base. Dasar (D) adalah unit lingual yang diimbuhi oleh afiks derivasi dan atau afiks infleksi dalam konteks morfologi derivasi dan infleksi (Katamba, 1993:45), dan sama dengan istilah 'bentuk dasar' yang digunakan Ramlan (1987:49) yakni satuan lingual, baik tunggal maupun kompleks, yang menjadi dasar bentukan bagi satuan yang lebih besar (bentuk turunan) seperti pakaian diturunkan dari (bentuk) D pakai, dan berpakaian diturunkan dari (bentuk) D pakaian.

Menurut Hurford \& Heasley (1983:206), proses morfologi derivasi merupakan tiga proses yang terjadi secara simultan yakni: (1) proses morfologi, (2) proses sintaksis, (3) proses semantis. Proses morfologi mengubah D yang menghasilkan turunan. Proses sintaksis mengubah kategori (baca: kelas kata, subkelas kata) seperti dari verba menjadi nomina, verba intransitif menjadi verba transitif. Proses semantik mengubah makna leksikal (leksem). Walaupun demikian, pendapat Hurford \& Heasley (1983:206) tentang derivasi yang mengalami proses sintaksis yakni mengubah kelas kata atau subkelas kata tidak sepenuhnya dijadikan patokan dalam penelitian ini. Bagaimanapun, sering ditemukan derivasi yang telah mengubah makna leksikalnya tetapi tidak mengubah kelas atau subkelas katanya.

Pemahaman tentang morfologi derivasi, Beard (2001:56) mengemukakan empat tipe derivasi yakni: (1) featural derivation (derivasi fitur), (2) fungtional derivation (derivasi fungsi), (3) tranposition (transposisi), dan (4) expressive derivation (derivasi ekspresi). Pertama, derivasi fitur adalah derivasi yang tidak mengubah kategori $D$, tetapi mengoperasikan nilai-nilai fitur inheren. Untuk hal ini, Beard (2001:56) mengemukakan contoh yang terbatas dalam bahasa Rusia yakni student (+feminine, +masculine) $\rightarrow$ studentka (+feminine, -masculine). Kedua, derivasi fungsi (disebut juga derivasi leksikal) adalah derivasi yang menambahkan fitur pada $D$, sehingga kata turunan itu berbeda secara semantis dari D seperti fish $\rightarrow$ fishery (lokatif of place), oak, wool $\rightarrow$ oaken, woolen (material). Ketiga, transposisi adalah derivasi yang mengubah kategori (kelas kata) seperti $\vee \rightarrow \mathrm{N}$ (walk $\rightarrow$ walking), $\mathrm{A} \rightarrow \mathrm{N}$ (new $\rightarrow$ newness), $\mathrm{N} \rightarrow \mathrm{A}$ (budget 
budgetary). Keempat, derivasi ekspresi adalah derivasi yang tidak mengubah wilayah referensi inputnya, dan juga tidak mengubah kategori $D$, tetapi memperlihatkan perbedaan nuansa makna ekspresinya. Derivasi ekspresi ini dalam bahasa Rusia seperti tiga golongan untuk 'hujan' dirasakan penutur yakni dozd (light), dozdik (beneficial), dan dozdicek (pleasant), dan semuanya mengacu pada konsep yang sama.

Proses morfologi derivasi adalah proses yang mengubah fitur makna leksikal. Untuk fitur makna leksikal ini, Tadjuddin (2005:32-35) mengemukakan istilah makna aksionalitas sebagai kategori leksiko-gramatikal (morfologi derivasi), bersifat tertutup, dan menghasilkan makna leksikal. Hal ini sesuai pula dengan Boiij (2005:135) yang menyatakan bahwa aspek predikasional (aspek leksikal dan diacu aktionsart dalam bahasa Jerman) adalah aspek yang ditentukan oleh verba seperti interpretasi duratif; dan dihasilkan oleh morfologi derivasi. Menurut Boiij (2005:135) lagi, aspek predikasional ini (Tadjuddin menyebut makna aksionalitas) berbeda dengan aspek gramatikal dalam infleksi seperti perfective dan imperfective.

Proses morfologi infleksi dalam bahasa-bahasa di dunia dikenal dengan konjugasi dan deklinasi. Konjugasi adalah alternasi infleksi pada verba, dan deklinasi adalah alternasi infleksi pada nomina dan pada kelas kata lain seperti pronomina dan adjektiva (Verhaar, 1999:121). Konjugasi (infleksi pada verba) mencakup: (1) kala, (2) aspek, (3) modus, (4) diatesis, (5) persona, jumlah, jenis menurut (Verhaar, 1999:126).

Kelima hal itu dijelaskan Verhaar (1999:126-133) sebagai berikut. Kala adalah hal yang menyangkut waktu atau saat (dalam hubungannya dengan saat penuturan) adanya atau terjadinya atau dilaksanakannya apa yang diartikan oleh verba seperti kala kini, lampau, futur. Aspek menyangkut salah satu segi dari apa yang diartikan oleh verba yaitu: adanya kegiatan atau kejadian (statif), mulainya (inkoatif), terjadinya (pungtual), berlangsungnya (duratif/progresif), selesai tidaknya (imperfektif jika belum selesai, perfektif jika selesai), adanya hasil atau tidak (resultatif jika ada hasil, nonresultatif jika tida ada hasil), dan adanya kebiasaan (habituatif). Modus adalah pengungkapan sikap penutur terhadap apa yang dituturkan dan secara infleksional sikap itu tampak dalam modus verbal seperti indikatif, subjungtif, optatif/desideratif, interogatif, negatif. Diatesis adalah bentuk verba transitif yang subjeknya dapat atau tidak dapat berperan agentif; diatesis dibedakan sebagai aktif, pasif, dan dalam bahasa tertentu juga sebagai medial. Selain itu, banyak bahasa memarkahi verba untuk persona (pertama, kedua, ketiga), jumlah (tunggal, jamak; dua, trial, paukal), jenis (maskulin, feminin, atau juga neutrum). 
Selain Verhaar, para ahli yang juga mengemukakan kategori infleksi pada verba adalah berikut ini. Beberapa kategori morfologi infleksi menurut Bauer (1988:74) yakni number, person, gender, tense, aspect, voice. Hatch and Brown (1995:225) dan Widdowson (1997:49) juga menyatakan berbagai proses penurunan verba yang tergolong dalam kategori morfologi infleksi adalah: (1) tense: present, past, future, (2) voice: aktif, pasif, (3) mood: indikatif, subjungtif, imperatif. Tiga kategori morfologi infleksi untuk verba tersebut juga dinyatakan oleh Radford et al. (1999:154-156) yakni tense, voice, dan mood. Stump (2001:2830) mengemukakan kategori infleksi pada verba yakni tense (past, present, future), aspect, voice dan mood. Set afiks verba lainnya yang termasuk kategori infleksi verba adalah person, number, gender. Boiij (2005:100,133-140), menyatakan dalam banyak bahasa terdapat kategori penting infleksi pada verba yakni tense (past, present, future), aspect (perfective, imperfective, etc), mood (indicative, subjunctive, imperative, etc), voice (active, passive, etc), number (singular, plural, etc.), person (first, second, third), dan gender.

Selain itu, dalam bahasa tertentu terdapat pula kategori infleksi dari segi ragam bahasa. Kategori infleksi ini dilihat berdasarkan pragmatik (kontekstual). Kiefer (2001:274) mengemukakan dalam bahasa Hungaria, pemilihan sufiks infleksi mempunyai konsekuensi stilistik. Makna stilistik sufiks berada dalam rentangan ragam tidak formal ke ragam formal. Selain itu, Boiij (2005:109) juga mengemukakan dalam bahasa Jerman, adjektiva atributif mempunyai dua pola infleksi kontekstual yang secara tradisional disebut: (1) infleksi lemah (weak inflection) yakni telah memiliki "definite article' dan infleksi kuat (strong inflection) yakni yang simpel/sederhana. Infleksi lemah adalah bentuk yang kurang formal (tidak formal), sedangkan infleksi kuat adalah bentuk yang formal secara kontekstual.

Berdasarkan uraian di atas, tampak bahwa masalah afiks derivasi per-/-an pada nomina turunan BI perlu dikaji. Pada artikel ini, teori morfologi derivasi dan infleksi digunakan untuk menjelaskan afiks derivasi per-/-an pada nomina turunan Bl. Artikel ini bertujuan untuk mengungkapkan proses afiksasi menggunakan afiks derivasi per-/-an pada nomina turunan BI berdasarkan teori morfologi derivasi dan infleksi.

\section{METODE}

Penelitian ini merupakan penelitian kualitatif dengan metode penelitian linguistik struktural dan memanfaatkan teori tata bahasa kasus Chafe (1970) dan Fillmore (1971) untuk hal semantis verba. Objek penelitian ini adalah afiks derivasi per-/-an pada nomina turunan BI. Data penelitian adalah kalimat (tuturan) yang di dalamnya terdapat nomina berafiks derivasi per-/-an. Sumber data adalah sumber 
tulis yakni tajuk rencana, berita dan artikel pada surat kabar. Sumber tulis lainnya yang digunakan adalah Kamus Besar Bahasa Indonesia (KBBI) edisi ketiga Depdiknas, 2005. Selain sumber tulis, digunakan pula sumber lisan yakni peneliti sendiri sebagai sumber data penelitian ini (Sudaryanto, 1993:161).

Metode analisis yang digunakan adalah metode agih yang dikemukakan oleh Sudaryanto (1993:15). Menurut Sudaryanto (1993:15) metode agih yakni metode analisis yang alat penentunya justru bagian dari bahasa itu sendiri. Teknik oposisi dua-dua digunakan untuk membandingkan fitur semantisnya dan menentukan afiks derivasi per-/-an. Teknik ubah wujud digunakan untuk menentukan fungsi dan makna (sintaksis) afiks derivasi per-/-an.

\section{PEMBAHASAN}

Proses derivasi yang berupa pengimbuhan afiks derivasi per-/-an pada $\mathrm{V}$ (baik verba dasar maupun verba turunan) dan $\mathrm{N}$ dapat menurunkan (1) $\mathrm{N}$ perbuatan, (2) N tindakan, (3) N instrumen tindakan, (4) N instrumen perbuatan, (5) N lokatif perbuatan, (6) N proses, (7) N kolektif, (8) N abstrak. Penjelasan proses derivasi tersebut dijelaskan berikut ini.

\section{Proses Derivasi: Afiks der per-/-an + V Perbuatan $\rightarrow N$ Perbuatan}

Proses derivasi yang berupa pengimbuhan afiks derivasi per-/-an pada $\mathrm{V}$ perbuatan ternyata menurunkan $\mathrm{N}$ perbuatan. Proses derivasi ini merupakan nominalisasi perbuatan. Hal ini dinyatakan dalam bentuk rumusan berikut ini.

\section{per-/-an + V perbuatan $\quad->\mathrm{N}$ perbuatan}

Karena mengubah kelas kata, proses derivasi ini disebut dengan proses derivasi transposisional.

Afiks derivasi per-/-an yang menurunkan $\mathrm{N}$ perbuatan dari $\mathrm{V}$ perbuatan (baik $\mathrm{V}$ dasar maupun $\mathrm{V}$ turunan) adalah seperti berikut.

1. Rasa lelah menempuh perjalanan udara dari Jakarta menuju Yogjakarta.

2. Kita harus menghindar dari perbuatan tercela.

3. Perkemahan dilaksanakan minggu depan.

4. Perlariannya terkenal sanagt cepat.

5. Perseteruan mereka telah terjadi sejak lama.

6. Perkelahian itu terjadi seminggu yang lalu.

7. Obama membantah spekulasi bahwa dia akan mengungkapkan inisiatif perdamaian baru.

8. Perkataan orang itu sangat menyinggung perasaanku.

9. Perdagangan lukisan berkibar lancar.

10. Perjuangan Kalla memperebutkan kursi RI-1 masih panjang dan berliku.

11. Tiga ribu orang berhasil keluar dari medan pertempuran. 
Pada contoh di atas terdapat $\mathrm{N}$ perbuatan perjalanan, perbuatan, perkemahan, perlarian, perseteruan, perkelahian, perdamaian, perkataan, perdagangan, perjuangan. Proses afikasasi derivasi ini adalah pengimbuhan afiks derivasi per-/-an pada $\mathrm{V}$ perbuatan seperti jalan, berbuat, berkemah, lari, berseteru, berkelahi, berdamai, berkata, berdagang, berjuang. Pengimbuhan afiks derivasi per-/-an pada $\mathrm{V}$ perbuatan (baik $\mathrm{V}$ dasar maupun $\mathrm{V}$ turunan) berfungsi menurunkan $\mathrm{N}$ perbuatan atau nominalisasi perbuatan ( $\mathrm{V}$ perbuatan $\rightarrow \mathrm{N}$ perbuatan). Perbedaan kelas kata $\mathrm{D}$ (input) dengan $\mathrm{N}$ (output) diketahui dengan tes keanggotaan kategorial kata dan teknik oposisi dua-dua seperti berikut ini.

$\begin{array}{lll}\text { NOMINA } & \text { DASAR } & \text { PROSES AFIKSASI } \\ \text { N perbuatan } & \text { V perbuatan } & \\ \text { perjalanan }(\mathrm{N}) & ><\text { jalan }(\mathrm{V}) & \text { afiks der per-/-an }+\mathrm{V} \text { perb. } \\ \text { perbuatan }(\mathrm{N}) & ><\text { berbuat }(\mathrm{V}) & \text { afiks der per-/-an }+\mathrm{V} \text { perb. } \\ \text { perkemahan }(\mathrm{N}) & ><\text { berkemah }(\mathrm{V}) & \text { afiks der per-/-an }+\mathrm{V} \text { perb. } \\ \text { perlarian }(\mathrm{N}) & >\text { lari }(\mathrm{V}) & \text { afiks der } \text { per-/-an }+\mathrm{V} \text { perb. } \\ \text { perseteruan }(\mathrm{N}) & ><\text { berseteru }(\mathrm{V}) & \text { afiks der per-/-an }+\mathrm{V} \text { perb. } \\ \text { perkelahian }(\mathrm{N}) & >\text { berkelahi }(\mathrm{V}) & \text { afiks der per-/-an }+\mathrm{V} \text { perb. } \\ \text { perdamaian }(\mathrm{N}) & ><\text { berdamai }(\mathrm{V}) & \text { afiks der per-/-an }+\mathrm{V} \text { perb. } \\ \text { perkataan }(\mathrm{N}) & >\text { berkata }(\mathrm{V}) & \text { afiks der per-/-an }+\mathrm{V} \text { perb. } \\ \text { perdagangan }(\mathrm{N}) & ><\text { berdagang }(\mathrm{V}) & \text { afiks der per-/-an }+\mathrm{V} \text { perb. } \\ \text { perjuangan }(\mathrm{N}) & ><\text { berjuang }(\mathrm{V}) & \text { afiks der per-/-an }+\mathrm{V} \text { perb. }\end{array}$

Berdasarkan identifikasi dan oposisi kelas kata $\mathrm{N}$ turunan dengan $\mathrm{D}$, afiks derivasi per-/-an berfungsi mengubah kelas kata $\mathrm{V}$ perbuatan menjadi $\mathrm{N}$ perbuatan (Vperb. $\rightarrow$ Nperb.) dan berarti pula mengubah leksem $V$ menjadi leksem $N$. Pada contoh di atas, afiks derivasi per-/-an- mengubah leksem $\vee J A L A N, B E R B U A T$, BERKEMAH, LARI, BERSETERU, BERKELAHI, BERDAMAI, BERKATA, BERDAGANG, BERJUANG menjadi leksem N PERJALANAN, PERBUATAN, PERKEMAHAN, PERLARIAN, PERSETERUAN, PERKELAHIAN, PERDAMAIAN, PERKATAAN, PERDAGANGAN, PERJUANGAN.

\section{Proses Derivasi: Afiks der per-/-an + V Tindakan $\rightarrow N$ Tindakan}

Proses derivasi yang berupa pengimbuhan afiks derivasi per-/-an pada $\mathrm{V}$ tindakan juga menurunkan $\mathrm{N}$ tindakan. Proses derivasi ini merupakan nominalisasi tindakan. Hal ini dinyatakan dalam bentuk rumusan berikut ini.

\section{per-/-an + V tindakan $\quad->\mathrm{N}$ tindakan}

Karena mengubah kelas kata, proses derivasi ini disebut dengan proses derivasi transposisional.

Afiks derivasi per-/-an yang menurunkan $\mathrm{N}$ tindakan dari $\mathrm{V}$ tindakan (baik $\mathrm{V}$ dasar maupun $\mathrm{V}$ turunan) adalah seperti berikut.

12. Djokovic memberikan perlawanan yang cukup sengit. 
13. la pulang ke kampung karena permintaan orang tuanya.

14. Amerika Serikat setuju untuk menghentikan percobaan senjata nuklir.

15. Badan meteorologi, klimalogi dan geofisika informasikan hasil perkiraan cuaca demi kelancaran pemungutan suara.

16. Pergelaran bunga itu antara lain memamerkan bunga angrek dan tanaman hisa.

17. Pesawat militer perlu ditambah untuk pertahanan negara kita.

18. Aku harus melanjutkan perjuangan diriku.

19. Kegiatan ini dilaksanakan berdasarkan persetujuan dari beberapa pihak.

Pada contoh di atas terdapat $\mathrm{N}$ tindakan perlawanan, permintaan, percobaan, perkiraan, pergelaran, pertahanan, perjuangan, persetujuan. Proses afikasasi derivasi ini adalah pengimbuhan afiks derivasi per-/-an pada $\mathrm{V}$ tindakan seperti lawan, minta, coba, perkirakan, pergelarkan, pertahankan, perjuangkan, setujui. Pengimbuhan afiks derivasi per-/-an pada $\mathrm{V}$ tindakan (baik $\mathrm{V}$ dasar maupun $\mathrm{V}$ turunan) berfungsi menurunkan $\mathrm{N}$ tindakan atau nominalisasi tindakan ( $V$ tindakan $\rightarrow \mathrm{N}$ tindakan). Perbedaan kelas kata $\mathrm{D}$ (input) dengan $\mathrm{N}$ (output) diketahui dengan tes keanggotaan kategorial kata dan teknik oposisi dua-dua seperti berikut ini.

\begin{tabular}{|c|c|c|}
\hline NOMINA & DASAR & PROSES AFIKSASI \\
\hline $\mathrm{N}$ tindakan & V tindakan & \\
\hline perlawanan $(\mathrm{N})$ & $><\operatorname{lawan}(\mathrm{V})$ & afiks der per-/-an $+V$ tind. \\
\hline permintaan $(\mathrm{N})$ & $><\operatorname{minta}(\mathrm{V})$ & afiks der per-/-an + V tind. \\
\hline percobaan $(\mathrm{N})$ & $><\operatorname{coba}(\mathrm{V})$ & afiks der per-/-an $+V$ tind. \\
\hline perkiraan $(\mathrm{N})$ & $><$ perkirakan $(\mathrm{V})$ & afiks der per-/-an $+\mathrm{V}$ tind. \\
\hline pergelaran $(\mathrm{N})$ & $><$ pergelarkan $(\mathrm{V})$ & afiks der per-/-an + $V$ tind. \\
\hline pertahanan $(\mathrm{N})$ & $><$ pertahankan $(\mathrm{V})$ & afiks der per-/-an $+V$ tind. \\
\hline perjuangan $(\mathrm{N})$ & $><$ perjuangkan $(\mathrm{V})$ & afiks der per-/-an $+V$ tind. \\
\hline persetujuan $(\mathrm{N})$ & $><$ setujui(V) & afiks der per-/-an $+V$ tind. \\
\hline
\end{tabular}

Berdasarkan identifikasi dan oposisi kelas kata $\mathrm{N}$ turunan dengan $\mathrm{D}$, afiks derivasi per-/-an berfungsi mengubah kelas kata $\mathrm{V}$ tindakan menjadi $\mathrm{N}$ tindakan (Vtind. $\rightarrow$ Ntind.) dan berarti pula mengubah leksem $V$ menjadi leksem N. Pada contoh di atas, afiks derivasi per-/-an- mengubah leksem $\vee$ LAWAN, MINTA, COBA, PERKIRAKAN, PERGELARKAN, PERTAHANKAN, PERJUANGKAN, SETUJUI menjadi leksem N PERLAWANAN, PERMINTAAN, PERCOBAAN, PERKIRAAN, PERGELARAN, PERTAHANAN, PERJUANGAN, PERSETUJUAN.

Proses Derivasi: Afiks der per-/-an + V Tindakan $\rightarrow N$ instrumen Tindakan

Proses derivasi yang berupa pengimbuhan afiks derivasi per-/-an pada $\mathrm{V}$ tindakan ternyata juga menurunkan $\mathrm{N}$ instrumen tindakan. Walaupun dengan 
data yang sangat terbatas, proses derivasi ini merupakan nominalisasi instrumen tindakan. Hal ini dinyatakan dalam bentuk rumusan berikut ini.

\section{per-/-an + V tindakan $\quad->\mathbf{N}$ instrumen tindakan}

Karena mengubah kelas kata, proses derivasi ini disebut dengan proses derivasi transposisional.

Afiks derivasi per-/-an yang menurunkan $\mathrm{N}$ instrumen tindakan dari $\mathrm{V}$ tindakan adalah seperti berikut.

20. BN2TKI minta Mennakertrans segera mencabut peraturan Mennakertrans.

Pada contoh di atas terdapat $\mathrm{N}$ instrumen tindakan peraturan. Proses afikasasi derivasi ini adalah pengimbuhan afiks derivasi per-/-an pada $\mathrm{V}$ tindakan atur. Pengimbuhan afiks derivasi per-/-an pada $\mathrm{V}$ tindakan ini berfungsi menurunkan $\mathrm{N}$ instrumen tindakan atau nominalisasi instrumen tindakan ( $\mathrm{V}$ tindakan $\rightarrow \mathrm{N}$ instrumen tindakan). Perbedaan kelas kata $\mathrm{D}$ (input) dengan $\mathrm{N}$ (output) diketahui dengan tes keanggotaan kategorial kata dan teknik oposisi duadua seperti berikut ini.

NOMINA

\section{$\mathbf{N}$ instrumen tind}

peraturan $(\mathrm{N})$

\section{DASAR}

\section{V tindakan}

$><\operatorname{atur}(\mathrm{V})$
PROSES AFIKSASI

afiks der per-/-an $+\mathrm{V}$ tind

Berdasarkan identifikasi dan oposisi kelas kata $\mathrm{N}$ turunan dengan $\mathrm{D}$, afiks derivasi per-/-an berfungsi mengubah kelas kata $\mathrm{V}$ tindakan menjadi $\mathrm{N}$ instrumen tindakan (Vtind. $\rightarrow \mathrm{N}$ instrumen tind.) dan berarti pula mengubah leksem $\mathrm{V}$ menjadi leksem N. Pada contoh di atas, afiks derivasi per-/-an- mengubah leksem V ATUR menjadi leksem N PERATURAN.

Proses Derivasi: Afiks der per-/-an + V Perbuatan $\rightarrow N$ Instrumen Perbuatan

Proses derivasi yang berupa pengimbuhan afiks derivasi per-/-an pada $\mathrm{V}$ perbuatan menurunkan $\mathrm{N}$ instrumen perbuatan. Walaupun dengan data yang juga terbatas, proses derivasi ini merupakan nominalisasi instrumen perbuatan. Hal ini dinyatakan dalam bentuk rumusan berikut ini.

\section{per-/-an + V perbuatan $\quad-->\mathrm{N}$ instrumen perbuatan}

Karena mengubah kelas kata, proses derivasi ini disebut dengan proses derivasi transposisional.

Afiks derivasi per-/-an yang menurunkan $\mathrm{N}$ instrumen perbuatan dari $\mathrm{V}$ perbuatan adalah seperti berikut.

21. Kawanan penjahat bersenjata api berhasil membawa 5 kilogram perhiasan emas.

22. Perusahaan harus mengikuti aturan pemerintah.

Pada contoh di atas terdapat $\mathrm{N}$ instrumen perbuatan perhiasan dan perusahaan. Proses afikasasi derivasi ini adalah pengimbuhan afiks derivasi per-/an pada $\mathrm{V}$ perbuatan berhias, berusaha. Pengimbuhan afiks derivasi per-/-an 
pada $\mathrm{V}$ perbuatan ini berfungsi menurunkan $\mathrm{N}$ instrumen perbuatan atau nominalisasi instrumen perbuatan ( $V$ perbuatan $\rightarrow \mathrm{N}$ instrumen perbuatan). Perbedaan kelas kata $\mathrm{D}$ (input) dengan $\mathrm{N}$ (output) diketahui dengan tes keanggotaan kategorial kata dan teknik oposisi dua-dua seperti berikut ini.

NOMINA

$\mathrm{N}$ instrumen perb.

perhiasan $(\mathrm{N})$

perusahaan $(\mathrm{N})$
DASAR

\section{V perbuatan}

$><$ berhias $(\mathrm{V})$

$><$ berusaha $(\mathrm{V})$

\section{PROSES AFIKSASI}

afiks der per-/-an + V perb.

afiks der per-/-an + V perb.

Berdasarkan identifikasi dan oposisi kelas kata $\mathrm{N}$ turunan dengan $\mathrm{D}$, afiks derivasi per-/-an berfungsi mengubah kelas kata $\mathrm{V}$ perbuatan menjadi $\mathrm{N}$ instrumen perbuatan (Vperb. $\rightarrow \mathrm{N}$ instrumen perb.) dan berarti pula mengubah leksem $\mathrm{V}$ menjadi leksem $\mathrm{N}$. Pada contoh di atas, afiks derivasi per-/-anmengubah leksem $\mathrm{V}$ BERHIAS, BERUSAHA menjadi leksem $\mathrm{N}$ PERHIASAN, PERUSAHAAN.

\section{Proses Derivasi: Afiks der per-/-an + V Perbuatan $\rightarrow N$ Lokatif Perbuatan}

Proses derivasi yang berupa pengimbuhan afiks derivasi per-/-an pada $\mathrm{V}$ perbuatan menurunkan $\mathrm{N}$ lokatif perbuatan. Proses derivasi ini merupakan nominalisasi lokatif perbuatan. Hal ini dinyatakan dalam bentuk rumusan berikut ini.

\section{per-/-an + V perbuatan $\quad-->\mathrm{N}$ lokatif perbuatan}

Karena mengubah kelas kata, proses derivasi ini disebut dengan proses derivasi transposisional.

Afiks derivasi per-/-an yang menurunkan $\mathrm{N}$ lokatif perbuatan dari $\mathrm{V}$ perbuatan adalah seperti berikut.

23. Perguruan tinggi tersebut menawarkan bebas tes masuk.

24. Para gadis menuju pemandian.

25. Pelabuhan itu mampu menggerakan roda perekonomian.

Pada contoh di atas terdapat $\mathrm{N}$ lokatif perbuatan perguruan, pemandian, dan pelabuhan. Proses afikasasi derivasi ini adalah pengimbuhan afiks derivasi per-/-an pada $\mathrm{V}$ perbuatan berguru, mandi, dan berlabuh. Pengimbuhan afiks derivasi per-/-an pada $\mathrm{V}$ perbuatan ini berfungsi menurunkan $\mathrm{N}$ lokatif perbuatan atau nominalisasi lokatif perbuatan ( $\mathrm{V}$ perbuatan $\rightarrow \mathrm{N}$ lokatif perbuatan). Perbedaan kelas kata $\mathrm{D}$ (input) dengan $\mathrm{N}$ (output) diketahui dengan tes keanggotaan kategorial kata dan teknik oposisi dua-dua seperti berikut ini.

NOMINA

N lokatif perb.

perguruan $(\mathrm{N})$

pemandian $(\mathrm{N})$

\section{DASAR}

\section{V perbuatan}

$><$ berguru $(\mathrm{V})$

$><$ mandi $(\mathrm{V})$

\section{PROSES AFIKSASI}

afiks der per-/-an + V perb. afiks der per-/-an $+V$ perb. 
pelabuhan (N) $\quad><$ berlabuh $(\mathrm{V}) \quad$ afiks der per-/-an + V perb

Berdasarkan identifikasi dan oposisi kelas kata $\mathrm{N}$ turunan dengan $\mathrm{D}$, afiks derivasi per-/-an berfungsi mengubah kelas kata $\mathrm{V}$ perbuatan menjadi $\mathrm{N}$ lokatif perbuatan (Vperb. $\rightarrow \mathrm{N}$ lokatif perb.) dan berarti pula mengubah leksem $\mathrm{V}$ menjadi leksem N. Pada contoh di atas, afiks derivasi per-/-an- mengubah leksem V BERGURU, MANDI, BERLABUH menjadi leksem N PERGURUAN, PEMANDIAN, PELABUHAN.

\section{Proses Derivasi: Afiks der per-/-an + V Proses $\rightarrow$ N Proses}

Proses derivasi yang berupa pengimbuhan afiks derivasi per-/-an pada $\mathrm{V}$ proses menurunkan $\mathrm{N}$ proses. Proses derivasi ini merupakan nominalisasi proses. Hal ini dinyatakan dalam bentuk rumusan berikut ini.

\section{per-/-an + V proses --> N proses}

Karena mengubah kelas kata, proses derivasi ini disebut dengan proses derivasi transposisional.

Afiks derivasi per-/-an yang menurunkan $\mathrm{N}$ proses dari $\mathrm{V}$ proses adalah seperti berikut.

26. Djoko Kirmanto membahas perkembangan infrastruktur sepanjang bangunan.

27. Ekonomi global akan kembali ke jalur pertumbuhan ekonomi yang berkesinambungan.

28. Hal itu jangan menimbulkan perpecahan dalam gerakan nasional.

29. Pertambahan penduduk Indonesia tidak seimbang dengan produksi bahan makanan.

30. Perubahan global yang pesat menuntut kesiapan pemerintah.

Pada contoh di atas terdapat $\mathrm{N}$ proses perkembangan, pertumbuhan, perpecahan, pertambahan, perubahan. Proses afikasasi derivasi ini adalah pengimbuhan afiks derivasi per-/-an pada $\mathrm{V}$ proses berkembang, tumbuh, pecah, bertambah, berubah. Pengimbuhan afiks derivasi per-/-an pada $V$ proses ini berfungsi menurunkan $\mathrm{N}$ proses atau nominalisasi proses ( $\mathrm{V}$ proses $\rightarrow \mathrm{N}$ proses). Perbedaan kelas kata $\mathrm{D}$ (input) dengan $\mathrm{N}$ (output) diketahui dengan tes keanggotaan kategorial kata dan teknik oposisi dua-dua seperti berikut ini.

NOMINA

N proses

perkembangan $(\mathrm{N})$

pertumbuhan (N)

perpecahan $(\mathrm{N})$

pertambahan $(\mathrm{N})$

perubahan $(\mathrm{N})$
DASAR

\section{V proses}

$><$ berkembang $(\mathrm{V})$

$>$ tumbuh (V)

$><\operatorname{pecah}(\mathrm{V})$

$><$ bertambah $(\mathrm{V})$

$><\operatorname{berubah}(\mathrm{V})$
PROSES AFIKSASI
afiks der per-/-an + V pros.
afiks der per-/-an + V pros.
afiks der per-/-an + V pros.
afiks der per-/-an + V pros.
afiks der per-/-an $+V$ pros 
Berdasarkan identifikasi dan oposisi kelas kata $\mathrm{N}$ turunan dengan $\mathrm{D}$, afiks derivasi per-/-an berfungsi mengubah kelas kata $\mathrm{V}$ proses menjadi $\mathrm{N}$ proses (Vpros. $\rightarrow$ Npros.) dan berarti pula mengubah leksem $V$ menjadi leksem N. Pada contoh di atas, afiks derivasi per-/-an- mengubah leksem $\vee$ BERKEMBANG, TUMBUH, PECAH, BERTAMBAH, BERUBAH menjadi leksem N PERKEMBANGAN, PERTUMBUHAN, PERPECAHAN, PERTAMBAHAN, PERUBAHAN.

\section{Proses Derivasi: Afiks der per-/-an $+\mathbf{N} \rightarrow \mathbf{N}$ Kolektif}

Proses derivasi yang berupa pengimbuhan afiks derivasi per-/-an pada $\mathrm{N}$ menurunkan $\mathrm{N}$ kolektif. Proses derivasi ini merupakan nominalisasi kolektif. Hal ini dinyatakan dalam bentuk rumusan berikut ini.

\section{per-/-an + N $\quad$ - $>$ N kolektif}

Karena tidak mengubah kelas kata, proses derivasi ini disebut dengan proses derivasi taktransposisional.

Afiks derivasi per-/-an yang menurunkan $\mathrm{N}$ kolektif dari $\mathrm{N}$ adalah seperti berikut.

31. Bandara Husein dikelilingi pegunungan.

32. Pepohonan tumbuh di sekitar kawasan hutan.

33. Harimau mengganas di perkebunan penduduk.

34. Tiga perusahaan melakukan penebangan hutan perbatasan Sumsel-Jambi.

35. Suasana perkampungan sama seperti tahun sebelumnya.

36. Malam hari mencekam di perumahan Distrik Heram.

37. Situ dibuat untuk mengairi persawahan.

38. Patroli kapal perang dan kapal induk dilakukan di perairan Somalia.

39. Pusat perbelanjaan yang dilengkapi gedung perkantoran terus dibangun.

Pada contoh di atas terdapat $\mathrm{N}$ kolektif pegunungan, pepohonan, perkebunan, perbatasan, perkampungan, perumahan, persawahan, peraairan, perkantoran. Proses afikasasi derivasi ini adalah pengimbuhan afiks derivasi per-/an pada $\mathrm{N}$ gunung, pohon, kebun, batas, kampung, rumah, sawah, air, kantor. Pengimbuhan afiks derivasi per-/-an pada $\mathrm{N}$ ini berfungsi menurunkan $\mathrm{N}$ kolektif atau nominalisasi kolektif ( $\mathrm{N} \rightarrow \mathrm{N}$ kolektif). Perbedaan kelas kata $\mathrm{D}$ (input) dengan $\mathrm{N}$ (output) diketahui dengan tes keanggotaan kategorial kata dan teknik oposisi dua-dua seperti berikut ini.

$\begin{array}{lll}\text { NOMINA } & \text { DASAR } & \text { PROSES AFIKSASI } \\ \text { N kolektif } & \mathrm{N} & \\ \text { pegunungan }(\mathrm{N}) & ><\text { gunung }(\mathrm{N}) & \text { afiks der per-/-an }+\mathrm{N} \\ \text { pepohonan }(\mathrm{N}) & ><\text { pohon }(\mathrm{N}) & \text { afiks der } \text { per-/-an }+\mathrm{N} \\ \text { perkebunan }(\mathrm{N}) & ><\text { kebun }(\mathrm{N}) & \text { afiks der per-/-an }+\mathrm{N} \\ \text { perbatasan }(\mathrm{N}) & ><\text { batas }(\mathrm{N}) & \text { afiks der per-/-an }+\mathrm{N} \\ \text { perkampungan }(\mathrm{N}) & ><\text { kampung }(\mathrm{N}) & \text { afiks der per-/-an }+\mathrm{N}\end{array}$




$\begin{array}{lll}\operatorname{perumahan}(\mathrm{N}) & ><\operatorname{rumah}(\mathrm{N}) & \text { afiks der per-/-an }+\mathrm{N} \\ \operatorname{pesawahan}(\mathrm{N}) & ><\operatorname{sawah}(\mathrm{N}) & \text { afiks der per-/-an }+\mathrm{N} \\ \text { perairan }(\mathrm{N}) & ><\operatorname{air}(\mathrm{N}) & \text { afiks der per-/-an }+\mathrm{N} \\ \text { perkantoran }(\mathrm{N}) & ><\text { kantor }(\mathrm{N}) & \text { afiks der per-/-an }+\mathrm{N}\end{array}$

Berdasarkan identifikasi dan oposisi kelas kata $\mathrm{N}$ turunan dengan $\mathrm{D}$, afiks derivasi per-/-an berfungsi mengubah kelas kata $\mathrm{N}$ menjadi $\mathrm{N}$ kolektif ( $\mathrm{N} \rightarrow \mathrm{N}$ kolektif.) dan berarti pula mengubah leksem $\mathrm{N}$ menjadi leksem $\mathrm{N}$. Pada contoh di atas, afiks derivasi per-/-an- mengubah leksem N GUNUNG, POHON, KEBUN, BATAS, KAMPUNG, RUMAH, SAWAH, AIR, KANTOR menjadi leksem N PEGUNUNGAN, PEPOHONAN, PERKEBUNAN, PERBATASAN, PERKAMPUNGAN, PERUMAHAN, PERSAWAHAN, PERAAIRAN, PERKANTORAN.

\section{Proses Derivasi: Afiks der per-/-an + N $\rightarrow$ N Abstrak}

Proses derivasi yang berupa pengimbuhan afiks derivasi per-/-an pada $\mathrm{N}$ menurunkan $\mathrm{N}$ abstrak. Proses derivasi ini merupakan nominalisasi abstrak dari suatu N. Hal ini dinyatakan dalam bentuk rumusan berikut ini.

per-/-an + N $\mathrm{N} \quad-\rightarrow \mathrm{N}$ abstrak

Karena tidak mengubah kelas kata, proses derivasi ini disebut dengan proses derivasi taktransposisional.

Afiks derivasi per-/-an yang menurunkan $\mathrm{N}$ abstrak dari $\mathrm{N}$ adalah seperti berikut.

40. Segmen UKM makin diminati perbankan.

41. Perusahaan swasta dan penebang liar perorangan masih terus beraktivitas di dalam hutan.

42. Penduduk yang memiliki KTP lebih dari satu, merupakan persoalan administrasi kependudukan.

43. Indonesia jadi proyek percontohan pengembangan keuangan syariah.

44. Jepang dan China merupakan negara dengan perekonomian terbaik kedua di dunia.

Pada contoh di atas terdapat $\mathrm{N}$ abstrak perbankan, perorangan, persoalan, percontohan, perekonomian. Proses afikasasi derivasi ini adalah pengimbuhan afiks derivasi per-/-an pada $\mathrm{N}$ bank, orang, soal, contoh, ekonomi. Pengimbuhan afiks derivasi per-/-an pada $\mathrm{N}$ ini berfungsi menurunkan $\mathrm{N}$ abstrak atau nominalisasi abstrak ( $\mathrm{N} \rightarrow \mathrm{N}$ abstrak). Perbedaan kelas kata $\mathrm{D}$ (input) dengan $\mathrm{N}$ (output) diketahui dengan tes keanggotaan kategorial kata dan teknik oposisi duadua seperti berikut ini

$\begin{array}{lll}\text { NOMINA } & \text { DASAR } & \text { PROSES AFIKSASI } \\ \mathbf{N} \text { abstrak } & \mathbf{N} & \\ \text { perbankan }(\mathrm{N}) & ><\text { bank }(\mathrm{N}) & \text { afiks der per-/-an }+\mathrm{N} \\ \text { perorangan }(\mathrm{N}) & ><\text { orang }(\mathrm{N}) & \text { afiks der per-/-an }+\mathrm{N}\end{array}$


Afiks Derivasi Per-/-An dalam Bahasa Indonesia: Tinjauan dari Perspektif Morfologi Derivasi dan Infleksi (Ermanto dan Emidar)

$\begin{array}{lll}\operatorname{persoalan}(\mathrm{N}) & >\operatorname{soal}(\mathrm{N}) & \text { afiks der per-/-an }+\mathrm{N} \\ \operatorname{percontohan}(\mathrm{N}) & ><\operatorname{contoh}(\mathrm{N}) & \text { afiks der per-/-an }+\mathrm{N} \\ \text { perekonomian }(\mathrm{N}) & ><\text { ekonomi }(\mathrm{N}) & \text { afiks der per-/-an }+\mathrm{N}\end{array}$

Berdasarkan identifikasi dan oposisi kelas kata $\mathrm{N}$ turunan dengan $\mathrm{D}$, afiks derivasi per-/-an berfungsi mengubah kelas kata $\mathrm{N}$ menjadi $\mathrm{N}$ abstrak ( $\mathrm{N} \rightarrow \mathrm{N}$ abstrak.) dan berarti pula mengubah leksem $\mathrm{N}$ menjadi leksem $\mathrm{N}$. Pada contoh di atas, afiks derivasi per-/-an- mengubah leksem N BANK, ORANG, SOAL, CONTOH, EKONOMI menjadi leksem N PERBANKAN, PERORANGAN, PERSOALAN, PERCONTOHAN, PEREKONOMIAN.

\section{SIMPULAN}

Berdasarkan uraian di atas, dapat dikemukakan simpulan berikut ini. Ditinjau dari perspektif morfologi derivasi dan infleksi, pengimbuhan afiks derivasi per-/-an pada verba (baik verba dasar maupun verba turunan) dan pada nomina dapat menurunkan (1) nomina perbuatan seperti perjalanan, perbuatan, perkemahan, perlarian, (2) nomina tindakan seperti perlawanan, permintaan, percobaan, perkiraan, (3) nomina instrumen tindakan seperti peraturan, (4) nomina instrumen perbuatan seperti perhiasan, perusahaan, (5) nomina lokatif perbuatan seperti perguruan, pemandian, pelabuhan, (6) nomina proses seperti perkembangan, pertumbuhan, perpecahan, pertambahan, perubahan, (7) nomina kolektif seperti pegunungan, pepohonan, perkebunan, perbatasan, perkampungan, (8) nomina abstrak seperti perbankan, perorangan, persoalan, percontohan, perekonomian.

\section{DAFTAR RUJUKAN}

Alwi, Hasan, Soenjono Dardjowidjojo, Hans Lapoliwa, Anton M. Moeliono. 1998. Tata Bahasa Baku Bahasa Indonesia (Edisi Ketiga). Jakarta: Balai Pustaka.

Bauer, Laurie. 1988. Introducing Linguistic Morphology. Edinburgh: Edinburgh University Press.

Beard, Robert. 2001. "Derivation" dalam Andrew Spencer and Anold M. Zwicky (eds) The Handbook of Morfology. Malden: Blackwell Publishers

Boiij, Geert. 2005. The Grammar of Words: An Introduction to Linguistic Morphology. New York: Oxford University Press.

Hatch, Evelyn and Brown, Cheryl. 1995. Vocabulary, Semantics, and Language Education. Cambridge: Cambridge University Press. 
Hurford, James R \& Heasley, Brendan. 1983. Semantics: a coursebook. Cambridge: Cambridge University Press.

Katamba, Francis. 1993. Morfology. London: The Macmillan Press.

Kiefer, Ferenz. 2001. "Morphology and Pragmatics" dalam Andrew Spencer and Anold M. Zwicky (eds) The Handbook of Morphology. Malden: Blackwell Publishers

Radford, Andrew, Martin Atkinson, David Britain, Harald Clahsen, Andrew Spencer. 1999. Linguistic: An Introduction. Cambridge: Cambridge Unoiversity Press.

Ramlan, M. 1987. Ilmu Bahasa Indonesia, Morfologi: Suatu Tinjauan Deskriptif. Yogyakarta: CV Karyono

Stump, Gregory. 2001. "Inflection" dalam Andrew Spencer and Anold M. Zwicky (eds) The Handbook of Morfology. Malden: Blackwell Publishers

Tadjuddin, Moh. 2005. Aspektualitas dalam Kajian Linguistik. Bandung: Penerbit P.T. Alumni.

Verhaar, J.W.M. 1999. Asas-asas Linguistik Umum. Yogyakarta: Gadjah Mada University Press.

Widdowson, H.G. 1997. Linguistics. New York: Oxford University Press. 